\title{
FOREST SURVEYS AND WORKING PLANS IN MANITOBA ${ }^{1}$
}

\author{
By C. B. GILL \\ Manitoba Forest Service, Winnipeg, Manitoba
}

It is generally assumed that a forest survey must precede the working plan, but it does not necessarily follow that a working plan will succeed a forest survey. Many of our early surveys were done for special purposes in connection with exploration, land use, or the cutting of timber. Records were not kept in such form that the information could be used in working plans, and much of the area covered was later cleared for settlement or heavily burned.

The earliest timber estimating in Manitoba seems to have been done in connection with the advertisement of timber berths, the oldest of which were granted shortly after the Dominion of Canada acquired Rupertsland from the Hudson's Bay Company in 1871, while the oldest berth still in good standing was awarded in 1886. Some of the cruises were done by practical men who made a fair estimate, but in most cases the work was very sketchily done, or the applicants estimate was taken. The result was that, in many cases, the actual cut of saw timber was many times the amount advertised. There was some excuse for this system, in that the operators paid dues on the amount actually cut.

Reconaissance surveys were initiated in 1905, when the Dominion Forest Service embarked on a policy of setting aside certain non-agricultural blocks in the accessible area as Forest Reserves. The total area of these Forest Reserves in 1930 was 2,723 square miles. This type of survey was of value in land classification, but was too sketchy to be of much use for timber inventory purposes.

Forest inventories took a big step forward from 1926 on, when many thousands of square miles were cruised in the laying out of a pulpwood berth for the Manitoba Paper Company. The whole area was first mapped from the air by oblique photography, and type maps were produced for the guidance of the ground parties. Much waste land was eliminated, but this early aerial typing was not very satisfactory in the separation of the timber types.

Around a hundred men were employed on ground surveys during the summer of 1927 and 1928, each led by a graduate forester. All species were tallied down to a small diameter, and the coniferous species were worked out in cords for unit areas.

The depression of the 1930's halted all further inventory work, and reduced the annual cut to very low levels. The only timber in demand was fuelwood, and it was then that jack pine became established as a valuable fuel.

Fortunately sufficient inventory work had already been done so that it was possible with the help of aerial photographs and some special reconnaissance work to fill in the gaps and to present an estimate for the whole pro-

1. Paper presented at the fortieth annual meeting of the Canadian Society of Forest Engineers, Frederiction, N.B., October 4 to 7, 1948. 
vince. This estimate was published in 1934 as a bulletin entitled, "The Forests of Manitoba." The provincial authorities, who took over the natural resources in 1930, found this inventory written by J. D. B. Harrison and published by the Dominion Forest Service to be of great value in controlling the cut of the province as a whole.

The Manitoba inventory gave us a reasonably accurate figure for productive area, and a further division into softwood, mixedwood and hardwood areas. Recognizing the importance of the conservation of our softwood growing stock, an allowable annual depletion amounting to 41,000,000 cubic feet of standing timber was established. It is gratifying to be able to report that from 1930 to the present time the depletion from logging and fire has not exceeded the total allowable cut for that period, and indeed we have a sizable accumulated undercut. In the case of hardwood (mostly poplar) it has not been necessary to limit the cut, as the problem here is to find new uses for material which is growing much faster than it can be used.

It is recognized that the setting of an annual allowable cut for a whole province is of somewhat doubtful value. Naturally the demand is heaviest on the most accessible areas, while the loss from windfall, insects, disease and old age in the less accessible areas also may be heavy.

Following some rather sketchy ground surveys, the Duck Mountain Forest Reserve was brought under sustained yield management for spruce saw timber in 1934. The area of 1,426 square miles is divided into five Working Circles, each with its own annual allowable cut. Further survey work has been done from time to time, and an annual cut of jack pine has been calculated, as well as a budget for black spruce pulpwood. The original felling budget was arrived at by the use of empirical yield tables representing each of the age classes (20 year intervals). This was later changed to the Swedish Formula method based on diameters.

Following a very elaborate Working Plan Survey made by the Dominion in 1925 on the Sandilands Forest Reserve (189 square miles) a working plan was made, allowing for a very small cut of jack pine railway ties. Growth and improvement in market conditions permitted an expansion in the original allowable cut in 1938. In 1945 a resurvey was made, using strips one chain wide, spaced two miles apart. By rechecking the original 1925 survey (strips which were 10 to 20 chains apart) and comparing the estimate so based with an estimate based on the tally of original strips two miles apart, it became evident that a survey as done in 1945 was sufficiently accurate for the main types, jack pine and black spruce. A new felling budget for two Working Circles was initiated. This area is now supplying large quantities of hydro poles, lumber, ties, pulpwood, fuelwood and cross-arms. The allowable cut is expressed in cubic feet, and was arrived at by computing the increment between the two surveys of 1925 and 1945. The Turtle Mountain (109 square miles) was brought under management in 1936. Normal yield tables for poplar in Minnesota were used, and deductions were made for lower stocking. No forest survey was made but a land classification map showing timber conditions was used to help establish productive area, and density of 
stocking. The timber, mostly poplar, is cut for fuelwood, and a few sawlogs are taken out. The felling budget is expressed in cords.

During and following World War II tentative land classification examinations were made with the object of establishing areas in the accessible region, which should not be opened for settlement but which should be permanently dedicated as forest areas. The area, including the existing Forest Reserves amounted to 18,900 miles. Later plans extended the area further north along the Hudson Bay Railway and brought the area to 33,000 square miles.

It is our aim to make an inventory of this 33,000 square miles and to gradually bring it under sustained yield management in unit areas. Aerial surveys by the R.C.A.F. in 1946, 1947 and 1948 have already covered a large proportion of the area. Excellent photographs with a scale of approximately four inches to the mile are being produced. Progress is being made in producing base maps, but this is now the bottle-neck.

In the meantime, work is going ahead on ground surveys, and about 800 square miles have been covered in the period 1945-48. This work is being done rather intensively as much of the area may be logged for one or more products in a few years. In many cases photographs are not yet available or are old obliques, and this is another reason for the intensity of the survey. Strips or line plots are used, the interval varying from 10 to 40 chains, depending on the timber and the existence and quality of the photographs.

Included in the 33,000 square miles mentioned above, there is an area of about 3,000 square miles held under pulpwood agreement by the Manitoba Paper Company. This Company made an aerial survey of their holdings in 1940. During the last few years, work has proceeded on the making of type maps and ground checking. It is expected that the complete inventory will be available by next year, and that a Working Plan will be drawn up, based on the findings of the inventory.

The "sine qua non" for a working plan may be outlined as follows:-

(1) Inventory

(2) Accessibility and Markets

(3) Silvicultural Practice

(4) Consent of the Owner

(5) Records

The inventory may be very simple. We want the productive area, the stand per acre and the rotation age. A good base map may give us the former, but usually it is necessary to eliminate non-productive area by running sample strips or by the use of aerial photographs. The stand per acre must be arrived at by sampling. The problem is much simplified if only one product, such as pulpwood is used. The estimate is best made in cubic feet, but converting factors must be established for other products.

A working plan is of no use if the area is too inaccessible for harvesting. If it is accessible there must be a market for at least one major product. As markets improve all species and other products will come into use, in which case the felling budget may be expanded. If thinnings can be used, a further 
expansion is warranted. Although the aim is a steady supply of timber for local industries, there will be years of lessened demand. The unused surplus may be cut in years of good demand as "an extra" over and above the regular annual cut.

Silviculture may be very simple. Cut the over-mature timber, dead or windfallen timber first, then the most mature timber. Cut so as to secure another crop. Extra field staff will likely be needed.

If the timber as well as the land belongs to the province, we must have the consent of the Minister in charge of the Department. He in turn must have the consent of the Cabinet. At some time or other local interests will demand that the felling budget be boosted. This must be resisted by the local forest officers and the support of the Government is essential. A program of forestry publicity in the district concerned will help greatly in getting the local co-operation required. If the timber is controlled by a company, the consent of the Board of Directors must be obtained.

Records of cut must be carefully kept for each Working Circle. It will be found that this will involve extra work, therefore provision must be made for additional clerical staff. 